\title{
Calculating electric power and energy generated in small wind turbine-generator sets in very short-term horizon
}

\author{
Mirostaw Parol ${ }^{1, *}$, Barttomiej Arendarski ${ }^{2}$, Rafat Parol $^{1}$ \\ ${ }^{1}$ Warsaw University of Technology, Faculty of Electrical Engineering, Warszawa, Poland \\ ${ }^{2}$ IFF Fraunhofer, Magdeburg, Germany
}

\begin{abstract}
The issue of very short-term forecasting of power generated in renewable energy sources, including small wind turbine-generator sets, is getting more and more important. Because it is crucial/necessary to ensure reliable electricity supplies to consumers, it is a subject of a great significance in small energy micro-systems, which are commonly called microgrids. Small wind turbine-generator sets will be shortly characterized in this paper. Further on, typical characteristics of power generated by these units, dependent on the wind velocity, will be presented. Then results of sample calculations of electric power and energy generated by several wind turbine-generator sets of small installed capacity, in relation to the wind velocity and time intervals assumed for calculations, will be presented. On the basis of these calculations, estimation errors resulting from the magnitude of time intervals, assumed in the process of wind velocity averaging, will be determined. Some qualitative analysis of obtained estimates of electric powers and energies, in context of very short-term forecasts of these quantities, will be carried out. At the end of the paper observations and conclusions concerning analyzed subject, i.e. calculating the electric power and energy generated in small wind turbinegenerator sets in a very short-term horizon, will be provided.
\end{abstract}

\section{Introduction}

The issue of very short-term forecasting of power generated in renewable energy sources, including small wind turbine-generator sets, is getting more and more important. For the reason of necessity of ensuring reliable electricity supplies to consumers, it is a subject of a great significance in small energy micro-systems, which are commonly called microgrids.

For the reason of some difficulties in access to precise measurement data on wind velocity for particular heights and locations, the values of electric power and electrical energy that are expected to be generated by turbine-generator sets are often determined with one hour or a dozen or so minutes time resolution, using actual values or average values [1-7]. What is more, sometimes the electric power being generated as a result of wind turbines operation under low wind velocity conditions is not taken into account.

* Corresponding author: miroslaw.parol@ee.pw.edu.pl 
Such a behaviour, especially for small wind turbines, can, in the opinion of the paper authors, lead to not very precise estimations of electric power and electrical energy that is going to be generated. In particular, it can be of a great importance for different kinds of analyses being performed for low voltage microgrids. It refers for instance to the process of online balancing the energy being generated and the energy being received, forecasting the electric power and the electrical energy in the short-term and very-short-term time horizons, as well as predicting the amount of energy being generated for the purpose of economic analyses.

As the main thesis of the research being described in the article, the authors of the paper claim that the selection of the right time resolution (the choice of the length of the time interval, during which we assume that the value of wind velocity is stable and does not change) when performing any calculations or analyses is a very significant task and can have a great direct impact on the results being obtained. The paper contributes to the general knowledge resources on the topic of microgrids by showing the impact being discussed in a quantitative way, basing on the calculations performed for the set of sample wind turbines and real world examples of wind velocity daily profiles data. The authors also show that due to the partially exponential nature of the particular turbines generation curves, the applying of long averaging time periods leads to the significant underestimation of the true values of the levels of electric powers being generated. These findings are the clue and constitute the key aspect of the paper.

In the subsequent sections, the results of sample calculations of electric power and energy generated by several wind turbine-generator sets of small installed capacity, in relation to the wind velocity and time intervals assumed for calculations, will be presented in this paper. Moreover, estimation errors resulting from the magnitude of time intervals, assumed in the process of wind velocity averaging, will be determined on the basis of these calculations.

The data used for calculations being discussed in the paper, that is wind velocity values for selected days for all the seasons and one selected location, as well as information on electric power generation curves for small turbine-generator sets reflect the real world conditions.

The allocation of wind power generators in the grid structure is another issue that has an impact on the planning and future operation of such systems [8].

\section{Small wind turbine-generator sets}

The characteristics of wind turbine-generator sets, including very small ones, can be found among others in $[9,10]$.

Such turbine-generator sets can be divided into different groups, with regard to many different criteria. As a basic criterion we can use their electric powers. According to that criterion, wind turbine-generator sets can be classified as micro-, small and big ones. In this paper, only small wind turbines, that is turbine-generator sets of a generated power from $100 \mathrm{~W}$ to $50 \mathrm{~kW}$ are of our interest [10]. Small wind power plants are usually installed on the roofs of some buildings or placed over the ground level with the use of towers.

Some other criterion of division is the position of the axis of rotation of the rotor. Two kinds of wind turbine units can be distinguished in this case [9, 10]: Horizontal Axis Wind Turbines (HAWT) and Vertical Axis Wind Turbines (VAWT). The first ones are the ones installed in $95 \%$ of all practical cases.

The number of rotor blades is also important, as well as the position of rotor with regard to the direction of wind and to the position of tower (in HAWT type power plants). Among the HAWT type turbines, over the $90 \%$ of currently applied units are the three-blade ones 
of up-wind type [10]. One-, two-, and many-blade solutions are also applied from time to time.

The amount of electric power being generated in wind turbine-generator set, together with the amount of electrical energy being produced is proportional to the third power of wind velocity. In turn, the wind velocity depends on some climatic factors and on the height on which the nacelle with the rotor is placed. Moreover, amount of energy produced by wind unit depends among others on efficiency of whole generating set $[9,10]$.

Detailed advantages and disadvantages of generating units with rotor of HAWT and VAWT type have been given among others in [10].

Basic parameters of local wind turbine-generator sets, which were used for calculations discussed in the paper have been presented in [11]. The specification of parameters of three-blade units of HAWT type of the following rated powers: $300 \mathrm{~W}$, $500 \mathrm{~W}, 1 \mathrm{~kW}, 2 \mathrm{~kW}, 3 \mathrm{~kW}, 5 \mathrm{~kW}, 10 \mathrm{~kW}, 20 \mathrm{~kW}$ has been given there.

The table of actual generated power (in watts) with relation to the wind velocity, for velocities within the range from 4 to $20 \mathrm{~m} / \mathrm{s}$, for all of the types of wind generating units mentioned before, is also given in the mentioned literature source. The cut-in speed for all the wind turbine-generator sets, except for the $300 \mathrm{~W}$ one, is equal to $2,5 \mathrm{~m} / \mathrm{s}$. For the generating unit of generated power equal to $300 \mathrm{~W}$ it is $2,0 \mathrm{~m} / \mathrm{s}$. This data was used to determine the generation curves (relations determining the value of generated power with regard to the value of wind velocity $P(v)$ ) for each turbine-generator set through making some trends approximations in Microsoft Excel software. The curves have been presented in Fig. 1.
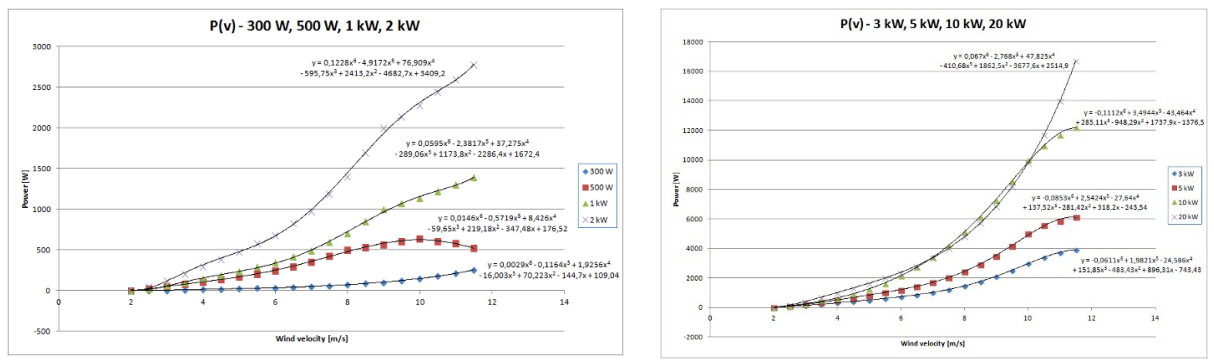

Fig. 1. Characteristics of power generated by wind units in function of wind velocity. Source: Own elaboration.

Resulting from the approximation calculations and shown in Fig. 1 for each turbinegenerator set curves $P(v)$ have been used later in further computations.

\section{Sample calculations of electric power and energy generated by wind turbine-generator sets of small installed capacity}

In the computations performed for the needs of this paper, only the velocity (and not its direction) of wind has been considered. The data set on wind velocity values has been based on some measurements taken in urban conditions, at the height of about $25 \mathrm{~m}$ [12].

Statistical analysis was based on data from four selected days: one day from spring, one day from summer, one day from autumn and one day from winter. The daily time series includes 2880 periods of 30 seconds each. Table 1 shows selected statistical measures of four mentioned time series of the wind velocity.

The minimum and maximum values for spring day, summer day and winter day time series are almost identical. In turn, the minimum and maximum values for autumn day are greater than for previous mentioned days. Similar relation holds for other statistical 
measures, i.e. the average velocity, the standard deviation and the variance. Only the value of the coefficient of variation for spring day is a little smaller than coefficient of variation value for summer day, autumn day and winter day time series.

Figure 2 shows the percentage frequency distribution of wind velocity for four time series. The wind velocity below $2.0 \mathrm{~m} / \mathrm{s}$ is dominant one for one time series (spring day). In turn, the wind velocity below $2.5 \mathrm{~m} / \mathrm{s}$ is dominant one for two time series (summer day, winter day). In the case of one time series (autumn day) the wind velocity below $3.5 \mathrm{~m} / \mathrm{s}$ is dominant one.

Table 1. Statistical measures for four time series of the wind velocity. Source: Own elaboration on the basis of [12].

\begin{tabular}{|l|c|c|c|c|}
\hline \multicolumn{1}{|c|}{ Statistical measures } & $\begin{array}{c}\text { Spring } \\
\text { day }\end{array}$ & $\begin{array}{c}\text { Summer } \\
\text { day }\end{array}$ & $\begin{array}{c}\text { Autumn } \\
\text { day }\end{array}$ & $\begin{array}{c}\text { Winter } \\
\text { day }\end{array}$ \\
\hline The length of the time series & 2880 & 2880 & 2880 & 2880 \\
\hline Max velocity [m/s] & 6.3 & 6.2 & 9.0 & 6.6 \\
\hline Min velocity [m/s] & 0.1 & 0.1 & 0.4 & 0.2 \\
\hline $\begin{array}{l}\text { The ratio of maximum velocity to minimum } \\
\text { velocity }\end{array}$ & 63 & 62 & 22.5 & 33 \\
\hline Average velocity [m/s] & 1.8115 & 2.0745 & 3.4623 & 2.1418 \\
\hline Standard deviation [m/s & 1.0963 & 0.9491 & 1.4820 & 1.0555 \\
\hline Variation [-] & 1.2019 & 0.9008 & 2.1963 & 1.1141 \\
\hline Coefficient of variation [\%] & 60.52 & 45.75 & 42.80 & 49.28 \\
\hline
\end{tabular}

The charts shown in Fig. 2 show, that during the measurement period the wind velocity value was most often within the range from $1.0 \mathrm{~m} / \mathrm{s}$ to $1.5 \mathrm{~m} / \mathrm{s}$ for spring day, from $1.5 \mathrm{~m} / \mathrm{s}$ to $2.0 \mathrm{~m} / \mathrm{s}$ for summer day and from $2.0 \mathrm{~m} / \mathrm{s}$ to $2.5 \mathrm{~m} / \mathrm{s}$ for autumn day and for winter day. For all the days (except for autumn day) the wind velocity values above the value of 4.5 $\mathrm{m} / \mathrm{s}$ rarely appeared. For autumn day the wind velocity values above the value of $6.5 \mathrm{~m} / \mathrm{s}$ are the ones that appeared rather occasionally.
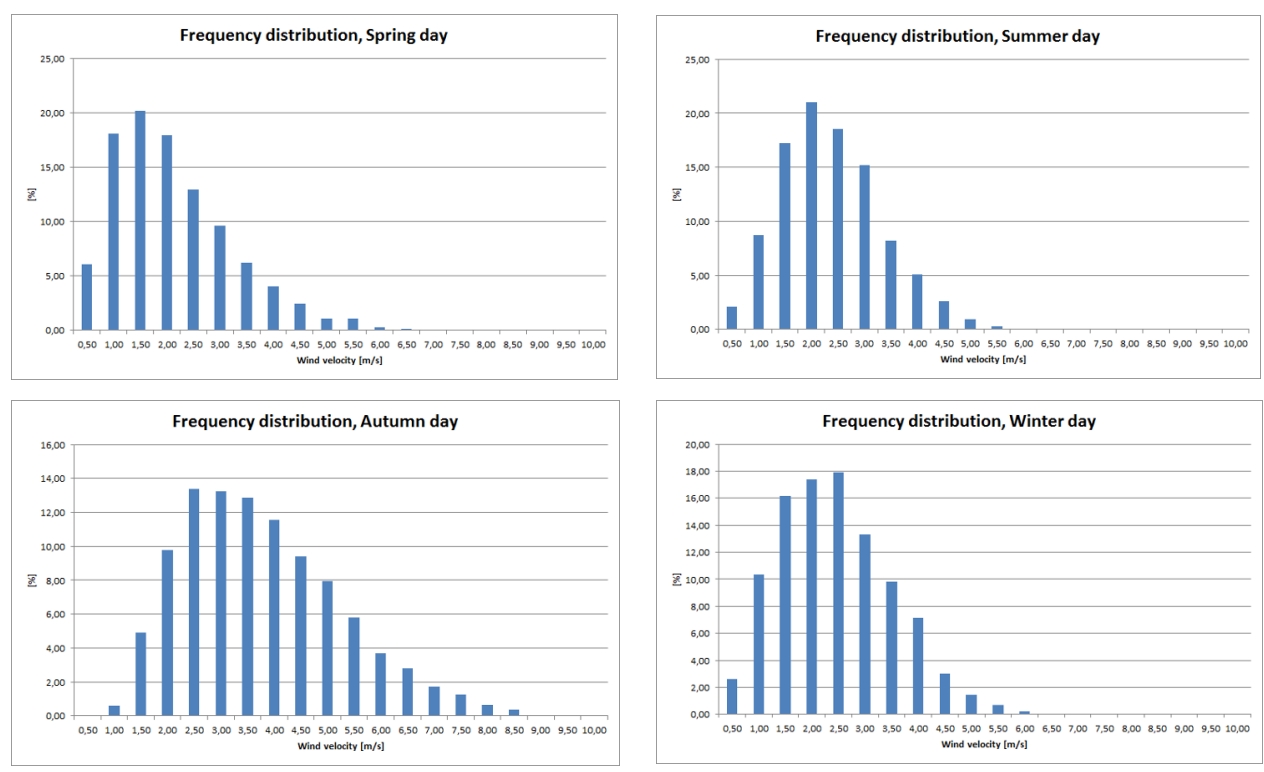

Fig. 2. The percentage frequency distribution of the wind velocity value for four time series. Source: Own elaboration.

The curves of power generated by analysed wind turbine-generator sets for one selected hour and averaging time period equal to $30 \mathrm{~s}$ in case of four time series (spring day, summer 
day, autumn day, and winter day) with regard to the time have been presented in Fig. 3. All of these figures show some great variability of the power that is being generated within a single hour of a day. As it can be noticed, the smallest variability among the analysed cases takes place for autumun day, which can be deduced also from the data presented in Table 1.
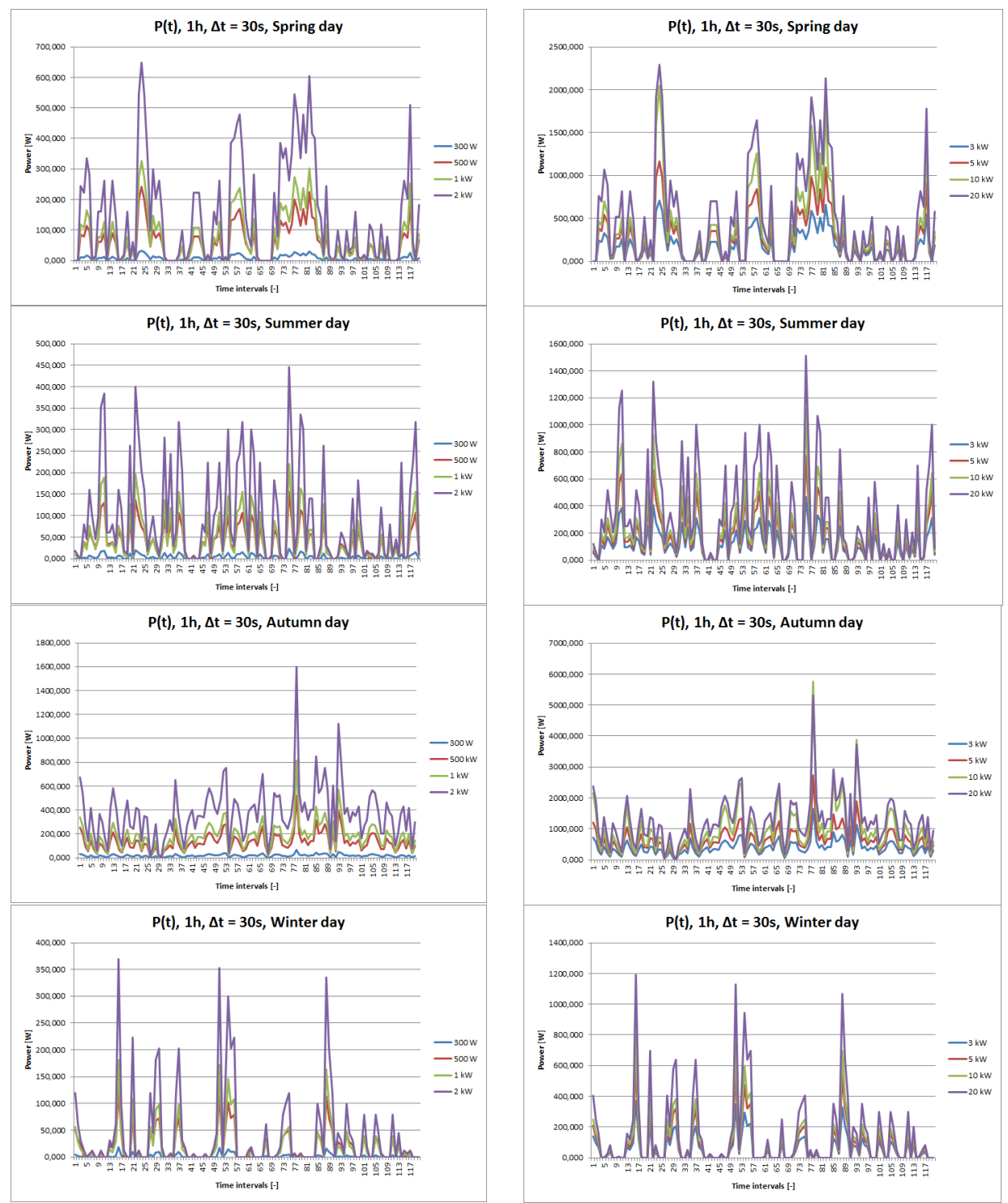

Fig. 3. The power generated by wind units for one selected hour and averaging time period equal to $30 \mathrm{~s}$ in case of four time series with regard to the time. Source: Own elaboration.

In turn, the bar charts of the energy generated by selected turbine-generator sets for 24 hours and averaging time period equal to $30 \mathrm{~s}$ in case of four time series (spring day, summer day, autumn day, and winter day) have been shown in Fig. 4. As it can be seen, for all the analysed days, the amount of generated energy depends on the rated power of wind generating unit. The biggest amount of energy is being prodcued by the wind turbine of rated power of $20 \mathrm{~kW}$, while the lowest amount by the wind turbine of rated power of 1 $\mathrm{kW}$. What is more, the amount of generated energy is not fully proportional to the rated 
power of the unit. The biggest amount of energy, due to weather conditions (see Table 1 and Fig. 1), is being generated by all the units during the autumn day.

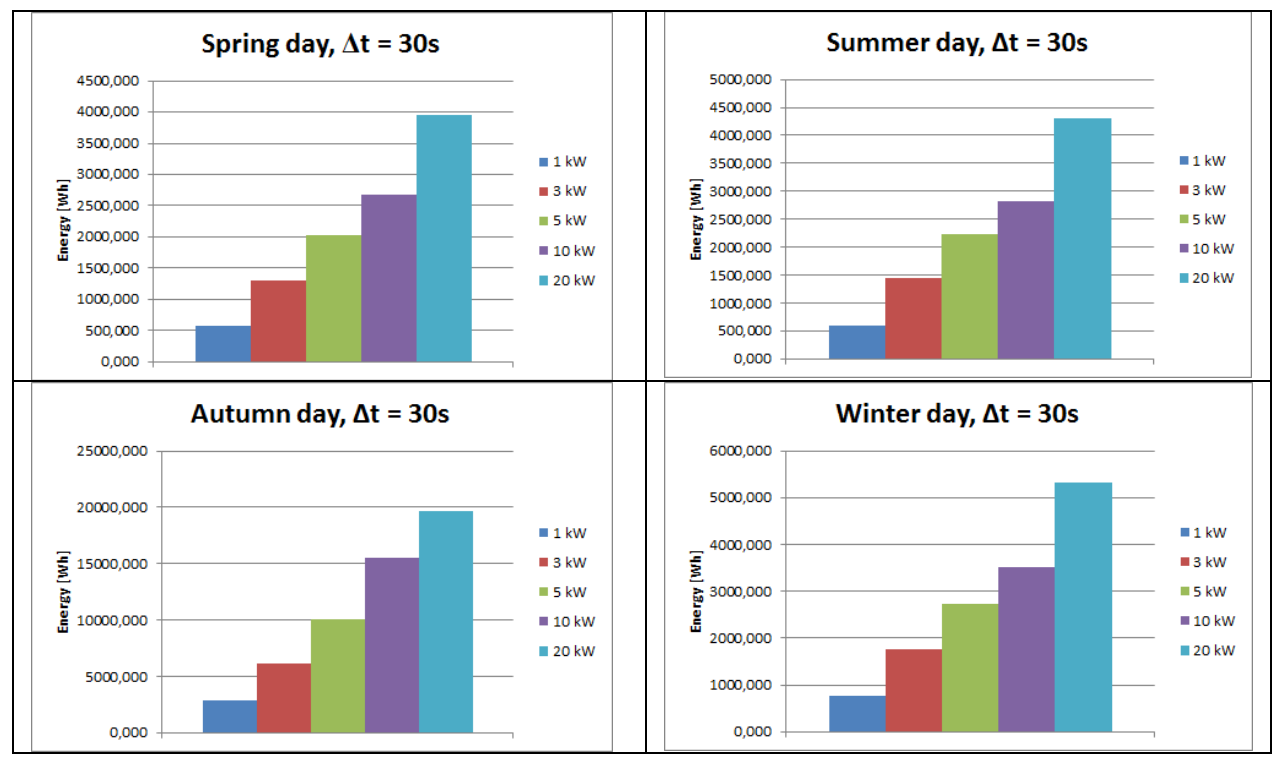

Fig. 4. The energy generated by selected wind units for 24 hours period of time and averaging time period equal to $30 \mathrm{~s}$ in case of four time series. Source: Own elaboration.

In Figure 5 curves of the power generated by wind turbine-generator sets for one selected autumn day and a few selected power capacity of these sets depending on averaging time periods have been presented. As it can be seen, calculated power that is generated by these wind turbines decreases with the increase of the averaging time period. The relation holds for all the analysed generating units, that is turbine-generator sets of rated power of $1 \mathrm{~kW}, 5 \mathrm{~kW}$ and $10 \mathrm{~kW}$. The shorter the averaging time period, which is obvious, the sharper the generated power curves.

In turn, in Fig. 6 the curves of energy generated by wind turbine-generator sets for one selected autumn day and a few selected power capacities of these units depending on averaging time period length have been shown. As it can be noticed, calculated values of energy generated by wind turbines decrease with the increase of averaging time period length. The amounts of energy being generated by units of rated power of $20 \mathrm{~kW}$ are the biggest, while the ones being generated by $1 \mathrm{~kW}$ units are the smallest. The curves differ depending on the particular day being analysed. Significant changes are being observed for summer day and for winter day, while the ones for spring day are relatively lower. The lowest changes appear for autumn day. It can be seen that for the 900-second (15-minute) averaging time periods and for longer ones the differences in calculated generated power are not so big for spring day and for autumn day. Similar observations are valid for 1200 -second (20-minute) and longer averaging time periods for summer day and for winter day.

The errors of calculated energy generated by wind turbine-generator sets for four days and a few selected power capacities of these units depending on averaging time period length have been presented in Fig. 7. The Sum of Squares (SoS) errors were taken into account. The basis for computing the errors was the calculated energy generated within the averaging period of time equal to 30s. As it can be observed, for three of the analysed days (spring day, summer day and winter day) the errors were the biggest for a generating unit of rated power equal to $20 \mathrm{~kW}$, while for a generating unit of rated power of $1 \mathrm{~kW}$ they were 
the smallest. In the case of autumn day, the errors for the $10 \mathrm{~kW}$ wind turbine were slightly greater than the ones for $20 \mathrm{~kW}$ wind turbine. SoS errors for bigger generating units $(10 \mathrm{~kW}, 20 \mathrm{~kW}$ of rated power) grow significantly with the increase of averaging time period length.

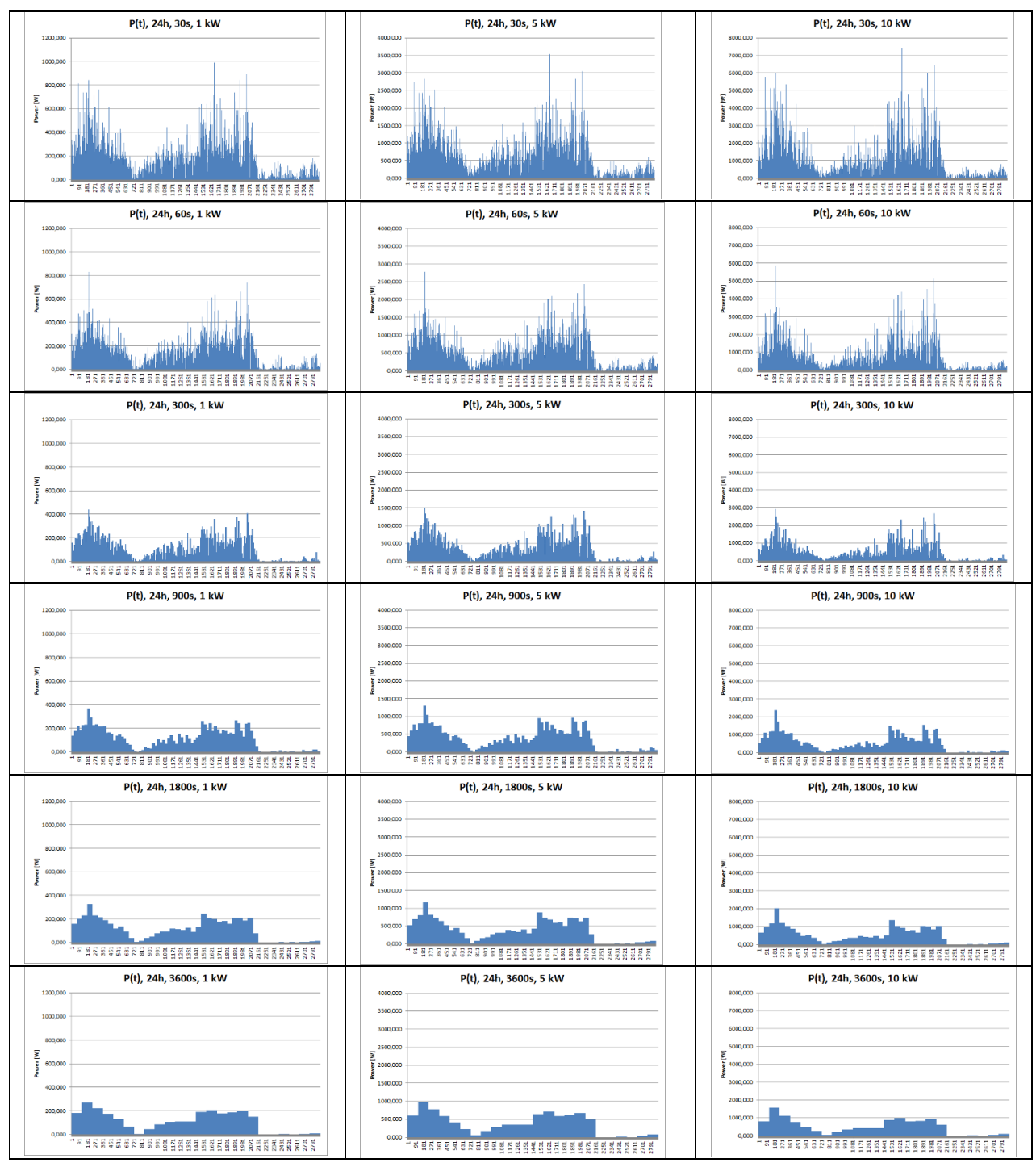

Fig. 5. The power generated by wind units for one selected autumn day and a few selected power capacities of these units depending on averaging time period length. Source: Own elaboration. 


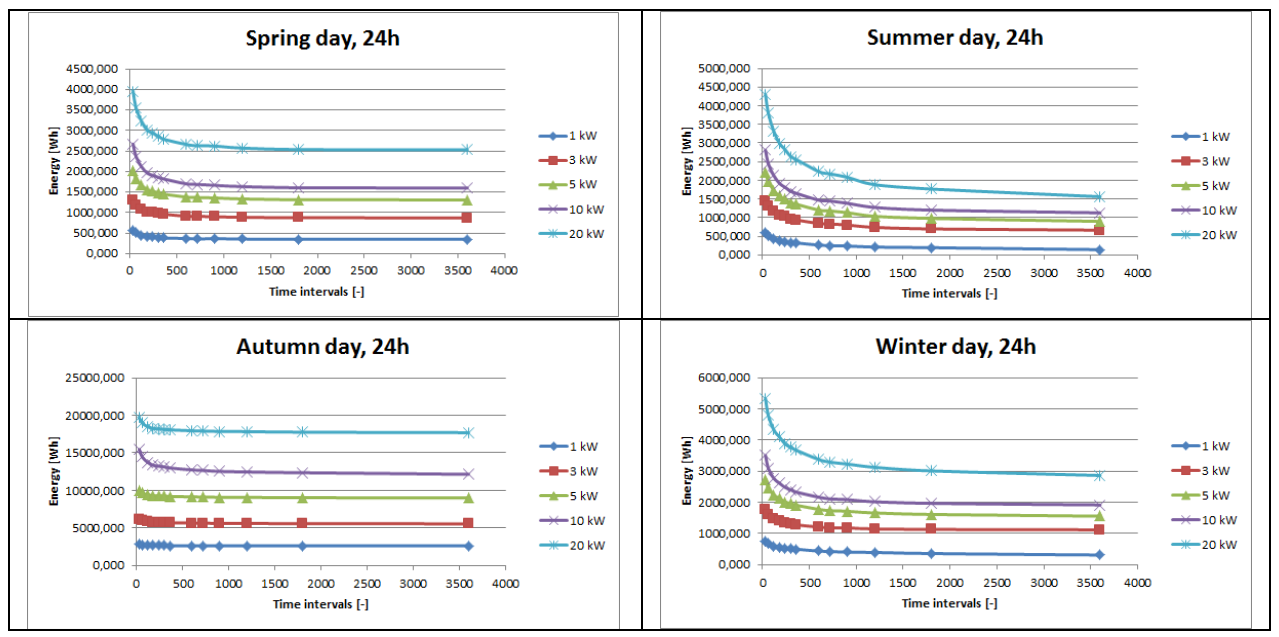

Fig. 6. The energy generated by wind units for one selected autumn day and a few selected power capacities of these units depending on averaging time period length. Source: Own elaboration.

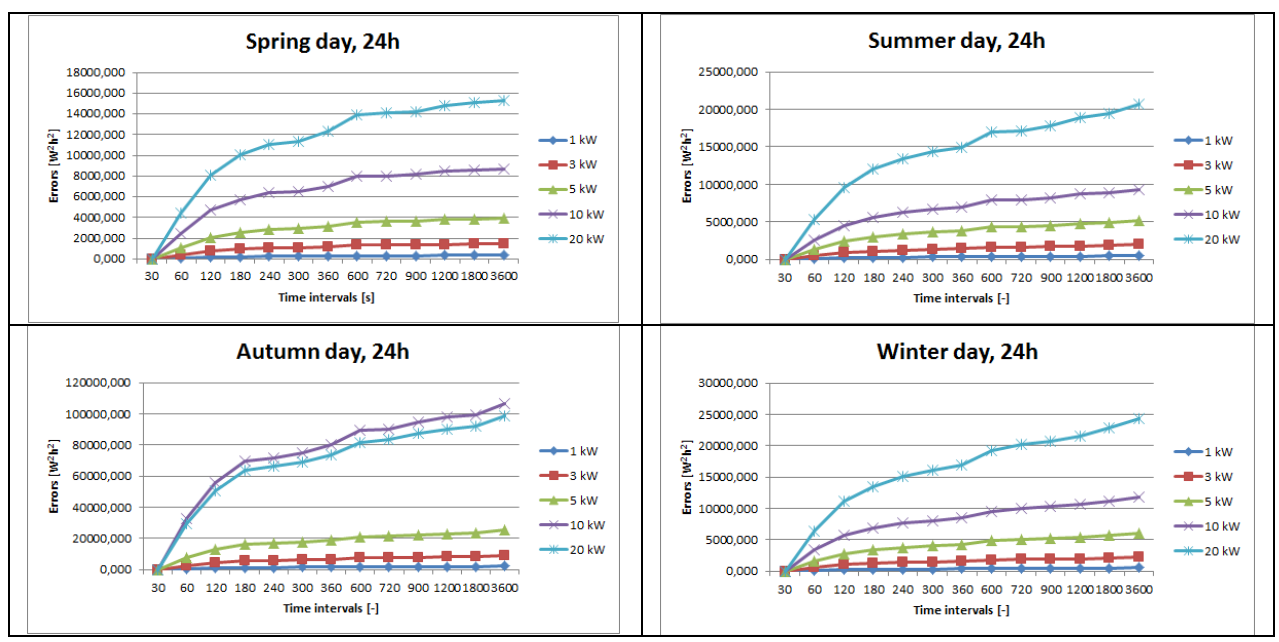

Fig. 7. The errors of calculated energy generated by wind units for four days and a few selected power capacities of these units depending on averaging time period length. Source: Own elaboration.

In very short-term forecasting task it is necessary to determine, possibly in the most precise way, the values of forecasted generated powers or electrical energies. As it was shown, averaging power or energy, which is often used, lead to not very precise estimations of electric power and electrical energy that is going to be generated by small wind turbinegenerator sets. It can be of a great importance for technical and economic analyses being performed for small electric power systems, e.g. in microgrids.

Data from Fig. 5 and Fig. 6 can serve as a good illustration of the scale of the problem. From Fig. 5 we know that in case of wind unit of rated power equal to $1 \mathrm{~kW}$ the maximum calculated generated powers for the averaging time periods: $30 \mathrm{~s}, 60 \mathrm{~s}, 5 \mathrm{~min}, 15 \mathrm{~min}, 30 \mathrm{~min}$ and $1 \mathrm{~h}$ are respectively: $998 \mathrm{~W}, 828 \mathrm{~W}, 439 \mathrm{~W}, 366 \mathrm{~W}, 325 \mathrm{~W}$ and $272 \mathrm{~W}$. Similar relations hold for wind turbines of other rated powers and sizes. In turn, from Fig. 6 we can find out that for summer day and $20 \mathrm{~kW}$ wind turbine-generator set calculated electric 
energies being generated for averaging time period lengths equal to: $30 \mathrm{~s}, 60 \mathrm{~s}, 5 \mathrm{~min}, 15$ min, $30 \mathrm{~min}$ and $1 \mathrm{~h}$ are respectively: $4300 \mathrm{Wh}, 3800 \mathrm{Wh}, 2641 \mathrm{Wh}, 2086 \mathrm{Wh}, 1769 \mathrm{Wh}$ and $1563 \mathrm{Wh}$. There is no doubt, that the choice of averaging time period length has a great direct impact on the quality of our very short-term forecasts, which can further influence the quality and precision of mentioned technical and economic analyses.

\section{Conclusions}

Observations and conclusions resulting from our studies and literature sources are presented below.

The issue of calculating the electric power and energy generated in small wind turbinegenerator sets in very short-term horizon has been discussed. The characteristics of wind turbine-generator sets, including very small ones, have been presented. Statistical analysis of the wind velocity was based on data from four selected days: one day from spring, one day from summer, one day from autumn and one day from winter.

Presented figures show some great variability of the power that is being generated within a day. The amount of energy generated by wind turbine-generator sets is not fully proportional to the rated power of the units. Calculated powers and energies that are generated by these wind turbines decrease with the increase of the averaging time period length. The shorter the averaging time period, which is obvious, the sharper the generated power curves. The Sum of Squares errors for bigger generating units grow significantly with the increase of averaging time period length.

Averaging power or energy, which is often used, lead to not very precise estimations of electric powers and electrical energies that are going to be generated by small wind turbinegenerator sets. The choice of averaging time period length has a great direct impact on the quality of very short-term forecasts, which can further influence the quality and precision of technical and economic analyses. It can have a big importance for small electric power systems, e.g. for microgrids.

The medium and low voltage networks are the main electric grids in which the RES based power plants are installed. Due to the volatile nature of these sources, the dynamics of such systems is increasing. In fact, there is a lack of the ICT (Information and communication technology) infrastructure and metering data of these networks, which are often not monitored. Therefore, the way of calculating the electric power and energy generated in small wind turbine-generator sets in very short-term horizon is of great importance for the future safe and reliable operation of such systems.

Data set on wind velocity used for calculations in this paper has been collected by the meteorology station of Photovoltaic Laboratory at Institute of Microelectronics and Optoelectronics of Warsaw University of Technology. The authors would like to thank very sincerely for sharing this data.

\section{References}

1. G. Sideratos, N. D. Hatziargyriou, An Advanced Statistical Method for Wind Power Forecasting. IEEE Trans. on Power Syst., 22, 1, February, 258-265 (2007)

2. S. S. Soman, H. Zareipour, O. Malik, P. Mandal, A Review of Wind Power and Wind Speed Forecasting Methods With Different Time Horizons, 42nd North American Power Symposium (NAPS 2010), Arlington, 26-28 September (2010)

3. Ch. Kang, Ch. Yong, X. Feng, X. Chuanzhi, S. Xiaofang, S. Dongkuo, D. Maosheng, Z. Jun, X. Li, S. Jiafeng, L. Xiaoyu, Ultra-short-term Wind Power Prediction and Its Application in Early-warning System of Power Systems Security and Stability, 4th 
IEEE International Conference on Electric Utility Deregulation and Restructuring and Power Technologies (DRPT), Weihai, 6-9 July (2011)

4. D. He, R. Liu, Ultra-short-term Wind Power Prediction Using ANN Ensemble Based on PCA, 7th International Power Electronics and Motion Control Conference - ECCE Asia, Harbin, 2-5 June (2012)

5. P. Piotrowski, Prognozowanie w elektroenergetyce $w$ różnych horyzontach czasowych, Prace Naukowe Politechniki Warszawskiej „Elektryka” 144 (Oficyna Wydawnicza Politechniki Warszawskiej, Warszawa, 2013)

6. M. Parol, Prognozowanie ultrakrótkoterminowe mocy generowanej w odnawialnych źródłach energii z wykorzystaniem logiki rozmytej, Przegląd Elektrotechniczny (Electrical Review), 90, 6, 265-268 (2014)

7. D. Baczyński, K. Księżyk, M. Parol, P. Piotrowski, J. Wasilewski, T. Wójtowicz, Mikrosieci niskiego napięcia. Praca zbiorowa pod redakcja M. Parola, (OWPW, Warszawa, 2013)

8. J. Alemany, F. Magnago, P. Lombardi, B. Arendarski, P. Komarnicki, Multiobjective Optimization Model for Wind Power Allocation, Mathematical Problems in Engineering, Volume 2017, Article ID 1876934, 1-10 (2017)

9. J. Paska, Rozproszone źródła energii. (OWPW, Warszawa, 2017)

10. K. Nalepa, W. Miąskowski, P. Pietkiewicz, J. Piechocki, P. Bogacz, Poradnik małej energetyki wiatrowej, Wojewódzki Fundusz Ochrony Środowiska i Gospodarki Wodnej, Olsztyn 2011

11. Przydomowe elektrownie wiatrowe, http://generatory-wiatrowe.pl/produkty/ elektrownie-wiatrowe/

12. Dane na temat prędkości wiatru ze stacji meteorologicznej Laboratorium Fotowoltaiki Instytutu Mikroelektroniki i Optoelektroniki Politechniki Warszawskiej 